\title{
BEBERAPA ASPEK BIOLOGI IKAN BILIH (Mystacoleucus padangensis) DI DANAU SINGKARAK
}

\author{
Kunto Purnomo1) dan Mas Tri Djoko Sunarno2) \\ 1) Peneliti pada Loka Riset Pemacuan Stok, Jatiluhur-Purwakarta \\ 2) Peneliti pada Pusat Riset Perikanan Tangkap, Ancol-Jakarta \\ Teregistrasi I tanggal: 10 Agustus 2009; Diterima setelah perbaikan tanggal: 20 Agustus 2009; \\ Disetujui terbit tanggal: 9 Nopember 2009
}

\begin{abstract}
ABSTRAK
Sebagai ikan endemik di Danau Singkarak dan ekonomis penting, ikan bilih (Mystacoleucus padangensis) menyumbang sekitar $71,2 \%$ dari total produksi ikan pada tahun 2003 dan cenderung menurun populasinya akibat tangkap lebih dan degradasi lingkungan. Untuk kelestarian ikan tersebut, antara lain perlu didukung oleh data dan informasi mengenai aspek biologinya. Oleh karena itu, suatu penelitian telah dilakukan untuk pengumpulan beberapa aspek biologi ikan bilih mulai bulan Agustus 2003-Oktober 2004 di Danau Singkarak. Contoh ikan bilih diambil dari stasiun penelitian yang ditetapkan secara sengaja di empat tempat. Contoh ikan diukur panjang dan bobotnya, isi saluran pencernaannya, serta diameter dan jumlah telurnya. Parameter pertumbuhan von Bertalanffy $\left(\mathrm{L}_{\infty}\right.$ dan $\left.\mathrm{K}\right)$, mortalitas alami $(\mathrm{M})$, mortalitas penangkapan $(\mathrm{F})$, mortalitas total $(Z)$, dan laju eksploitasi (E) dihitung dengan menggunakan data frekuensi panjang total, kemudian diolah dengan menggunakan program FISAT. Pola kebiasaan makan dari ikan dianalisis memakai indeks preponderan. Hasil penelitian ini menunjukkan bahwa panjang total ikan bilih berkisar 4,2-8,6 cm (rata-ratanya $6,2 \mathrm{~cm})$. Pertumbuhan ikan bilih bersifat alometrik positif $(p<0,05)$. Rasio ikan jantan dan betina adalah 2:1. Ikan betina mempunyai 5.830-7.390 butir telur per ekor atau 436-628 butir per gram bobot tubuh. Ikan bilih secara teoritis dapat tumbuh sampai mencapai panjang $11,6 \mathrm{~cm}\left(\mathrm{~L}_{\infty}\right)$ dengan laju pertumbuhan (K) $0,5 \mathrm{~cm}$ per tahun. Mortalitas alami (M) sebesar 1,46 $\operatorname{tahun}^{-1}$, Nilai mortalitas penangkapan $(F)=1,56$ tahun $^{-1}$ dan mortalitas total $(Z)=3,02$ tahun $^{-1}$ (kisarannya $2,47-3,55$ ) serta laju eksploitasi $(E)$ sebesar 0,52 . Makanan ikan bilih terdiri atas detritus $(38,9 \pm 7,1 \%)$, fitoplankton $(33,0 \pm 9,2 \%)$, zooplankton $(22,6 \pm 13,6 \%)$, dan tumbuhan air $(5,4 \pm 2,7 \%)$.
\end{abstract}

KATAKUNCl: ikan endemik, allometrik positif, mortalitas, laju eksploitasi, indeks preponderan

\section{PENDAHULUAN}

Danau Singkarak mempunyai luas 11.220 ha, ratarata kedalaman $136 \mathrm{~m}$ dan secara geografis terletak pada posisi $100^{\circ} 26^{\prime} 15^{\prime \prime}-100^{\circ} 35^{\prime} 5^{\prime \prime}$ BT dan $0^{\circ} 31^{\prime} 46^{\prime \prime}-$ $0^{\circ} 42^{\prime 2} 20^{\prime \prime}$ LS. Perairan Danau Singkarak tergolong agak subur (mesotrofik) dengan potensi produksi ikannya berkisar 4.463-21.279 ton/tahun (Purnomo, 1994). Selanjutnya, dari 17 jenis ikan yang menghuni danau ini, jenis ikan yang banyak tertangkap adalah ikan bilih, asang (Osteochilus brachinopterus), turiek (Cyclocheilichtys de Zwani), dan sasau (Hampala spp.).

Ikan bilih secara taksonomi termasuk ordo Ostariophysi, famili Cyprinidae, dan tergolong ikan endemik yang hanya ditemukan di Danau Singkarak (Kottelat et al., 1993). Sekitar $71,2 \%$ dari total hasil tangkapan tahun 2003 (1.332 ton) adalah ikan bilih (Purnomo, 2008). Ikan bilih mempunyai nilai ekonomis penting yang mempunyai pasar lokal dan ekspor ke Malaysia sehingga jenis ikan ini dijadikan ikan primadona dari Danau Singkarak. Harganya pada tahun 2004 di tingkat nelayan dalam keadaan basah atau segar mencapai Rp.18.000,-/kg, dan dalam keadaan kering mencapai Rp.70.000,-/kg.
Nilai ekonomis relatif tinggi memberikan dampak terhadap peningkatan eksploitasi sumber daya ikan bilih tanpa memperdulikan kelestarian sumber dayanya. Indikatornya adalah terjadi penurunan populasi dan ukuran individu ikan bilih dari $18,6 \mathrm{~cm}$ pada tahun 1988 (Anhariah, 1988) menjadi $5,9 \mathrm{~cm}$ pada tahun 2002 (Purnomo et al., 2003). Dari aspek enonomi, sekitar 700 nelayan di selingkar Danau Singkarak telah menurun pendapatan mereka dari Rp.100.000/orang/hari menjadi Rp.10.000 sejak tahun 2002. Oleh karena itu, suatu penelitian telah dilakukan dengan tujuan untuk pengumpulan data dan informasi mengenai aspek pertumbuhan, mortalias, preferensi makanan, dan biologi reproduksi ikan bilih di Danau Singkarak. Hasil penelitian ini diharapkan dapat dimanfaatkan sebagai bahan masukan dalam penyusunan rencana pengelolaan sumber daya ikan bilih di Danau Singkarak.

\section{BAHAN DAN METODE}

Penelitian ikan bilih ini dilakukan pada tahun 2003 dan 2004 di Danau Singkarak, Sumatera Barat. Penelitian ini menggunakan metode survei. Sebanyak empat stasiun penelitian ditetapkan secara sengaja di tempat-tempat penangkapan ikan bilih yang berada 


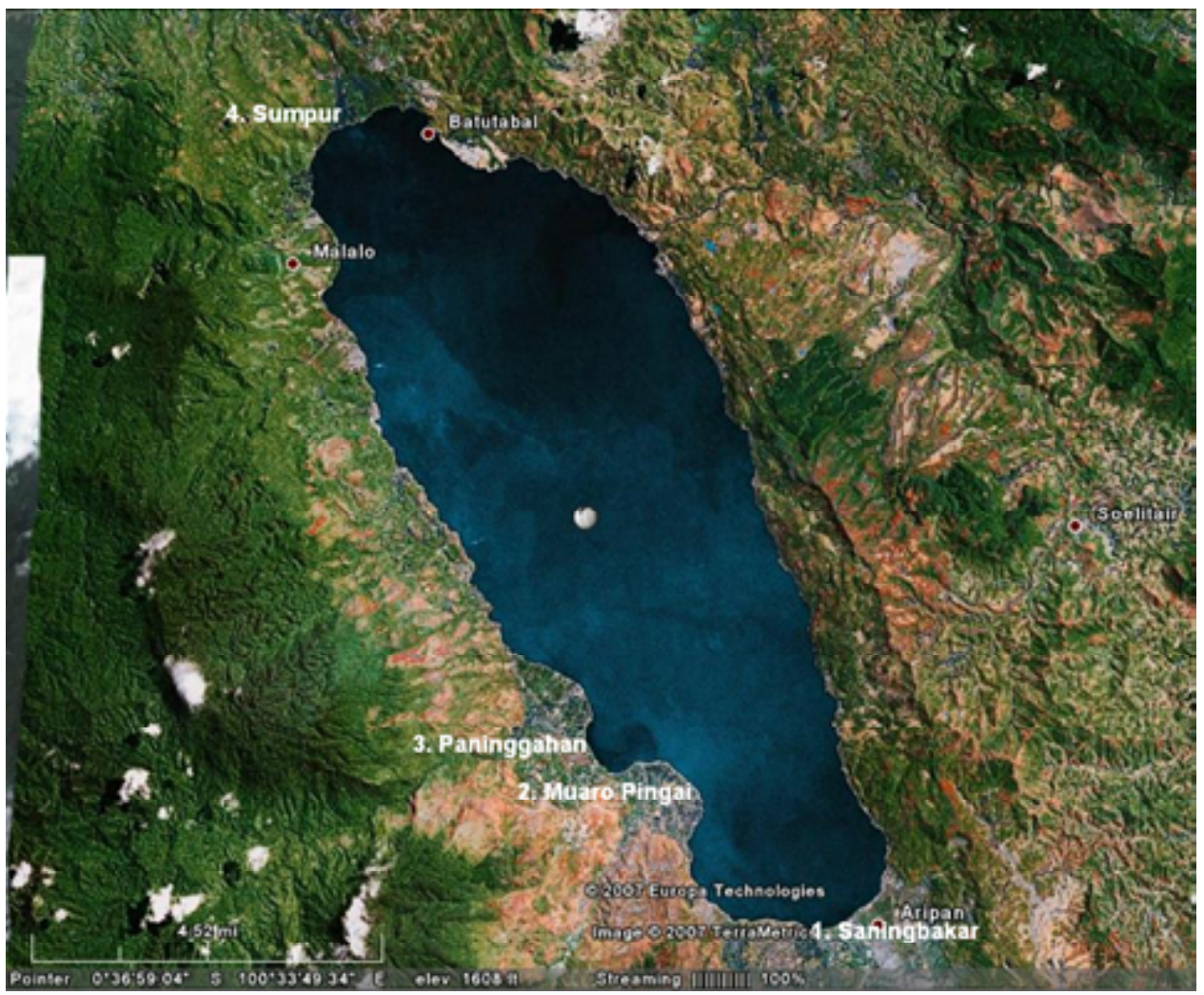

Gambar 1. Stasiun penelitian ikan bilih di Danau Singkarak.

di setiap Nagari (bentuk pemerintahan setingkat desa), yaitu 1) Saningbakar, 2) Muaro Pingai, 3) paninggahan, dan 4) Sumpur (Gambar 1). Di setiap stasiun, dilakukan pengambilan contoh ikan dan air pada pada bulan Agustus, Oktober, dan Desember 2003 serta Oktober 2004.

Contoh ikan diperoleh dari hasil tangkapan nelayan dengan alat alahan, jala, dan jaring insang (langli-nama lokal) berukuran mata jaring 0,75-1,50 inci. Ikan contoh diukur panjang (ketelitian 0,1 cm), bobot (ketelitian $0,01 \mathrm{~g}$ ) dan jenis kelaminnya berdasarkan pada ciri kelamin primer, kemudian dimasukan ke dalam kantong plastik berisi $4 \%$ formalin berlabel untuk pengamatan di Laboratoium Loka Riset Pemacuan Stok Ikan, Jatilihur. Di laboratorium, ikan dibedah dan diukur diameter dan jumlah telur, serta diamati isi saluran pencernaannya.

Kebiasaan makanan ikan diketahui berdasarkan pada data isi saluran pencernaan yang kemudian dianalisis dengan rumus Indeks Preponderan (Natarajan \& Jhingran dalam Prabha \& Manjulatha, 2008) sebagai berikut:

$$
I_{i}=\left\{\left(V_{i}^{*} O_{i}\right) / \Sigma\left(V_{i}^{*} O_{i}\right)\right\}^{*} 100 \%
$$

di mana:

$\mathrm{I}=$ indeks prepoderan jenis makanan ke- $\mathrm{i}$

$\mathrm{V}=$ persentase volume pakan ke-i

$\mathrm{O}_{i}^{\prime}=$ persentase kejadian pakan ke-i

Penghitungan fekunditas ditujukan hanya pada tingkat kematangan gonad (TKG) III dan IV ikan betina dengan menggunakan metode gravimetrik. Setelah ditimbang, gonad diambil cuplikan dari bagian ujung dan tengah gonad secara merata dan diamati di bawah mikroskop dengan perbesaran $4 \times 10$ serta kemudian dihitung jumlah butiran telurnya. Fekunditas dihitung menggunakan rumus dari Effendi (1979) sebagai berikut:

$$
F=\left(G^{*} X\right) / Q
$$

di mana:

$$
\begin{aligned}
& F=\text { fekunditas }(\text { butir) } \\
& G=\text { bobot gonad }(\mathrm{g}) \\
& X=\text { jumlah telur contoh (butir) } \\
& Q=\text { bobot telur contoh }(\mathrm{g})
\end{aligned}
$$

Data panjang dan bobot ikan tiap individu ikan dianalisis untuk mengetahui sifat pertumbuhannya, apakah isometrik $(b=3)$ atau alometrik $(b \neq 3)$. 
Penghitungan hubungan antara panjang dan bobot ikan memakai rumus:

$$
W=a^{*} L^{b}
$$

di mana:

$$
\begin{array}{ll}
\mathrm{W} & =\text { bobot ikan }(\mathrm{g}) \\
\mathrm{L} & =\text { panjang total }(\mathrm{cm}) \\
\mathrm{a} \text { dan } \mathrm{b} & =\text { konstanta }
\end{array}
$$

Nilai konstanta "b" yang diperoleh dari persamaan tersebut di atas selanjutnya diuji ketepatannya terhadap nilai $b=3$ menggunakan uji t. Pertumbuhan ikan dinyatakan dalam rumus pertumbuhan von Bertalanffy (VBGF) sebagai berikut:

$$
\mathrm{L}_{\mathrm{t}} \mathrm{L}_{\infty} \quad\left\{1-\mathrm{e}^{(-\mathrm{K}(\mathrm{t}-\mathrm{t} 0))}\right\}
$$

di mana:

$$
\begin{aligned}
& L_{t}=\text { prediksi panjang pada umur } \mathrm{t} \text { (tahun) } \\
& \mathrm{L}_{\infty}=\text { panjang asimptotik }(\mathrm{cm}) \\
& \mathrm{K}=\text { konstanta pertumbuhan } \\
& t_{0}=\text { umur ikan pada panjang nol (tahun) }
\end{aligned}
$$

Panjang asimtotik $\left(\mathrm{L}_{\curvearrowright}\right)$ dalam rumus pertumbuhan von Bertalanffy mula-mula diduga menggunakan modifikasi dari Wetherall Plot. Data frekuensi panjang tiap jenis ikan dijumlahkan dan kemudian digunakan untuk menduga $L$ and $Z / K$. Selanjutnya $L$ dipakai untuk menduga parameter pertumbuhan von Bertalanffy dengan menggunakan bantuan paket program FiSAT (Gayanilo et al., 1995). Koefisien mortalitas total (Z) dari stok ikan diduga menggunakan program FiSAT (Gayanilo et al., 1995). Dugaan Z diperoleh dari kurva tangkapan sebagai refleksi dari konversi panjang (length-converted catch curve) dan laju mortalitas alami (M) dari stok ikan dihitung menggunakan persamaan Pauly (Pauly, 1980) sebagai berikut:

Ln $M=-0,0152-0,279 * \operatorname{Ln} L_{\infty}+0,6543^{*} \operatorname{Ln} k+0,4634^{*} \operatorname{Ln} T$ . $(5$

di mana:

$\mathrm{T}=$ rata-rata suhu perairan Danau Singkarak, yaitu $27,0^{\circ} \mathrm{C}$

Koefisien mortalitas penangkapan $(F)$ dihitung dari persamaan $\mathrm{F}=\mathrm{Z}-\mathrm{M}$. Laju eksploitasi (E) dihitung menggunakan persamaan $E=F / Z$ (Pauly, 1980), dengan asumsi bahwa nilai optimum $F$ dari stok ikan yang dieksploitasi $\left(\mathrm{F}_{\text {opt }}\right)$ adalah sebanding dengan mortalitas alaminya (M) maka eksploitasi optimum $(E$ ) yang diharapkan adalah sama dengan 0,5 (Gülland, 1983). Pola rekruitmen diperoleh dengan memproyeksikan data frekuensi panjang terhadap waktu dengan menggunakan parameter pertumbuhan (Pauly, 1982). Hasil tangkapan relatif per rekruitmen $(\mathrm{Y} / \mathrm{R})$ dan biomassa relatif per rekruitmen $(\mathrm{B} / \mathrm{R})$ diduga menggunakan model Beverton and Holt yang dimodifikasi oleh Pauly \& Soriano (1986).

\section{HASIL DAN BAHASAN}

Hasil pengambilan contoh pengukuran panjangbobot individu ikan bilih jantan dan betina selama penelitian dari bulan Agustus 2003-Oktober 2004 di Danau Singkarak (Gambar 3) menunjukkan bahwa rata-rata ukuran panjang badan ikan bilih jantan dan betina masing-masing adalah $6,1 \mathrm{~cm}$ (kisaran 4,3$8,4 \mathrm{~cm}$ ) dan 6,2 cm (kisaran 4,2-8,6 cm). Hasil analisis hubungan panjang-bobot ikan bilih jantan, betina, dan gabungannya (sexes combined) memperlihatkan pola pertumbuhan seperti tertera pada Tabel 1.

Ikan bilih jantan, betina, dan gabungannya memperlihatkan nilai koefisien regresi $b>3$. Hasil uji statistik memakai uji-t terhadap nilai koefisien regresi $b=3$ memperlihatkan bahwa koefisien regresi b ikan bilih jantan sebesar 3,27 tersebut (Tabel 1) kisarannya (pada aras kepercayaan 5\%) antara 3,13-3,40. Koefisien regresi b ikan bilih betina 3,31 kisarannya (pada aras kepercayaan 5\%) antara 3,19-3,43 dan bila data ikan jantan dan betina digabung (gabungan) maka koefisien regresi b sebesar 3,29 kisarannya (pada aras kepercayaan 5\%) adalah 3,19-3,38. Dari nilai-nilai kisaran koefisien regresi $b$ tersebut ternyata nilai $b=3$ adalah tidak termasuk atau berada di luar kisaran nilai $b$ tersebut. Nilai-nilai koefisien regresi $b$ yang diperoleh (Tabel 1) dapat dikatakan lebih besar daripada tiga $(b>3)$, artinya pertumbuhan ikan bersifat allometrik positif, yaitu pertumbuhan bobot badan lebih cepat dibanding pertumbuhan panjangnya (Ricker, 1975). Menurut Dulčić et al. (2003), nilai konstanta b dipengaruhi oleh tingkat perkembangan ontogenetik seperti perbedaan umur, tingkat kematangan gonad, dan jenis kelamin. Dari Tabel 1 tersebut di atas tampak bahwa nilai konstanta $b$ ikan bilih betina lebih besar dibanding yang jantan, hal ini mengindikasikan bahwa pada ukuran yang sama ikan betina lebih besar dibanding yang jantan.

Hasil analisis terhadap panjang total ikan bilih (gabungan jantan dan betina) untuk mendapatkan nilai beberapa parameter populasi ikan bilih diperoleh nilai $\mathrm{L}_{\infty}=11,6 \mathrm{~cm}$ dan $\mathrm{k}=0,5$ per tahun (Gambar 4 ), artinya secara teoritis untuk kondisi saat ini ikan ini mampu tumbuh sampai mencapai panjang (total) $11,6 \mathrm{~cm}$ dengan laju pertumbuhan 0,5 per tahun. Nilai $\mathrm{L}_{\infty}$ tersebut lebih kecil dibanding nilai yang pernah 


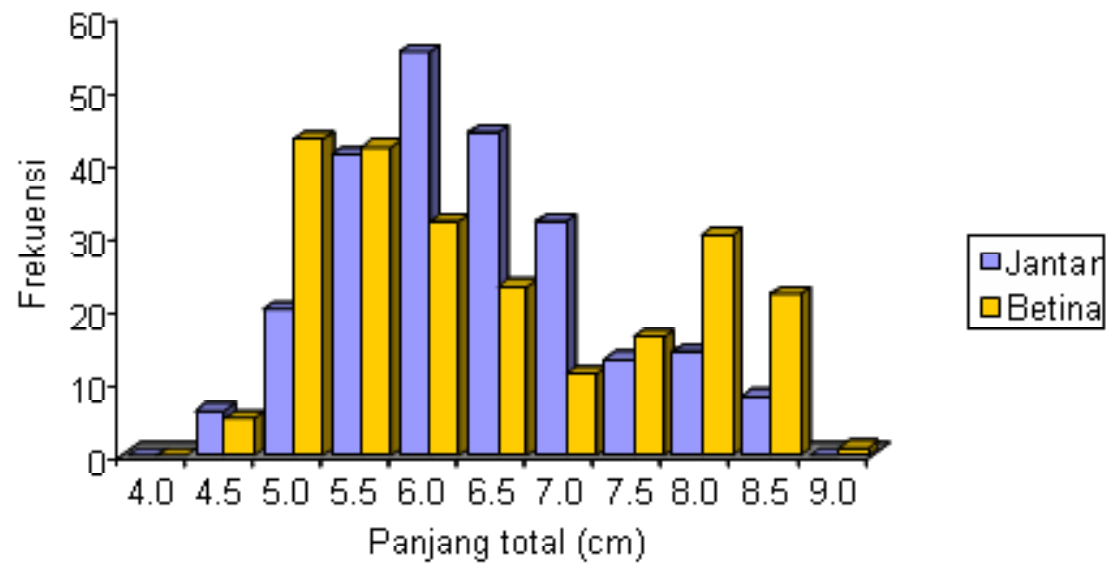

Gambar 3. Distribusi frekuensi panjang ikan bilih.

Tabel 1. Hubungan panjang-bobot ikan bilih

\begin{tabular}{lcccl}
\hline \multicolumn{1}{c}{ Jenis kelamin } & Persamaan & $\mathbf{R}^{2}$ & $\mathbf{n}$ & Pertumbuhan \\
\hline Jantan & $\mathrm{W}=0,0052 \mathrm{~L}^{3,27}$ & 0,91 & 233 & Alometrik \\
Betina & $\mathrm{W}=0,0045 \mathrm{~L}^{3,31}$ & 0,93 & 225 & Alometrik \\
Gabungan & $\mathrm{W}=0,0048 \mathrm{~L}^{3,29}$ & 0,92 & 458 & Alometrik \\
\hline
\end{tabular}

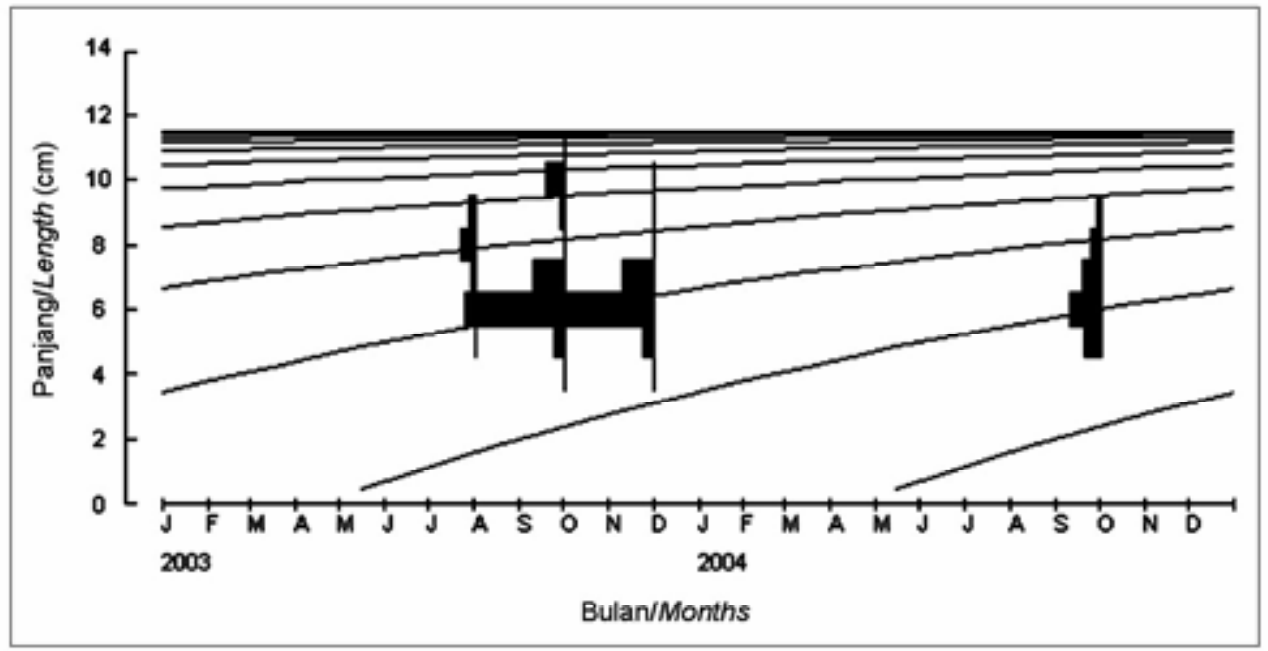

Gambar 4. Distribusi frekuensi panjang dan kurva pertumbuhan ikan bilih.

diperoleh Syandri (1996) pada tahun 1995 yaitu sebesar $14,6 \mathrm{~cm}$. Demikian pula dibandingkan temuan pada tahun 1988 dengan ukuran sebesar $18,6 \mathrm{~cm}$ (Anhariah, 1988).

Perbedaan tersebut mengindikasikan bahwa dalam rentang waktu sekitar 10 tahun telah terjadi penyusutan ukuran individu ikan bilih sehingga pantas bila dikatakan bahwa eksploitasi ikan bilih di Danau Singkarak sudah mencapai tingkatan lebih tangkap (overfishing). Informasi ini seyogyanya mendapat perhatian yang serius dari para pengelola sumber daya ikan di danau tersebut, misalnya dengan segera mengambil tindakan pengaturan jumlah dan jenis alat tangkap yang boleh dioperasikan (alat tangkap yang tidak ramah lingkungan segera diberantas). Parameter lainnya, adalah mortalitas alami (M) yang pada suhu udara $27,0^{\circ} \mathrm{C}$ adalah 1,46 per tahun, mortalitas penangkapan $(F)=1,56$ per tahun sehingga mortalitas total $(Z)=3,02$ dan laju eksploitasi sumber daya $(E) \quad 0,52$. Nilai $E$ tersebut mengindikasikan bahwa ada suatu upaya untuk mengurangi atau membatasi penangkapan ikan bilih dan memperbesar rekruitmen misalnya dengan restoking atau dapat juga dengan mengembangkan daerah-daerah suaka perikanan seperti yang direkomendasikan oleh Purnomo et al. (2006). 
Ikan bilih memiliki ciri kelamin sekunder yang dapat dipakai sebagai pedoman untuk pengenalan di lapangan, yaitu ikan bilih betina bentuk tubuhnya lebih gemuk dibanding yang jantan. Ikan bilih yang sudah matang gonad sirip ekornya berwarna kuning keemasan. Perbandingan antara ikan bilih jantan dan betina adalah $2: 1$, artinya di alam populasi ikan jantan lebih banyak dibanding ikan betina. Ikan bilih jantan mencapai matang gonad pertama kali pada ukuran panjang $6,2 \mathrm{~cm}$ sedangkan yang betina pada panjang $8,2 \mathrm{~cm}$. Berdasarkan pada pengalaman Syandri et al. (2001), dengan ukuran panjang $8,2 \mathrm{~cm}$ tersebut maka ikan tersebut sudah siap memijah. Fekunditasnya antara 5.830-7.390 butir per ekor, atau 436-628 butir per gram bobot tubuh (rata-rata 524 butir per gram bobot tubuh). Nilai rata-rata fekunditas tersebut jauh lebih rendah dibanding yang pernah diperoleh oleh Syandri (1996) yaitu 605 butir per gram bobot tubuh. Ada pun diameter telur ikan bilih adalah antara 625-725 mm.

Menurut Syandri (1996), ikan bilih memijah lebih dari satu kali setiap tahunnya, dan sifat pemijahannya adalah "parsial" artinya telur yang sudah matang tidak dikeluarkan sekaligus dalam satu periode pemijahan. Telur ikan bilih bersifat non demersal dan tidak melekat pada substrat dasar perairan sehingga telur-telur hasil pemijahan akan langsung dihanyutkan arus air sungai menuju ke danau dan akhirnya menetas (Purnomo et al., 2003; 2006). Hasil analisis terhadap distribusi frekuensi panjang badan memperlihatkan bahwa puncak pemijahan ikan bilih terjadi pada bulan JuliAgustus (Gambar 5). Pengalaman selama ini walau puncak pemijahan terjadi pada bulan Juli-Agustus namun setiap harinya ada ikan bilih yang memijah, hanya jumlahnya tidak sebanyak bulan-bulan tersebut tadi (Purnomo et al., 2006).

Hasil analisis isi perut terhadap 70 ekor ikan bilih selama penelitian menunjukkan bahwa makanan utama ikan tersebut adalah detritus $(38,9 \pm 7,1 \%)$ dan fitoplankton $(33,0 \pm 9,2 \%)$, sedangkan makanan pelengkap dan tambahannya masing-masing adalah zooplankton $(22,6 \pm 13,6 \%)$ dan tumbuhan air $(5,4 \pm$ $2,7 \%$ ). Tampaknya preferensi makanan ikan bilih cendrung berubah dengan bertambahnya ukuran panjang badan (Gambar 6). Ketika berukuran kecil makanan utamanya adalah detritus dan fitoplankton, tetapi dengan bertambahnya ukuran panjang badan maka makanan utama tadi berubah menjadi zooplankton sebagai makanan utama dan detritus menjadi makanan pelengkapnya. Perubahan preferensi makanan tersebut erat kaitannya dengan umur ikan dan ketersediaan makanan di alam (makanan alami).

Fitoplankton yang paling banyak dikonsumsi terutama adalah dari famili Bacillariophyceae (genera Navicula sp. dan Cymbella sp.). Menurut Purnomo (2008), fitoplankton yang dikonsumsi ikan bilih mirip dengan ketersediaan atau kelimpahannya di alam (Danau Singkarak) di mana kelimpahan plankton di tersebut didominansi oleh famili Bacillariophyceae $(48,6 \%)$. Keterkaitan antara ketersediaan makanan di alam dan yang dikonsumsi tersebut cukup kuat, hal ini seperti diindikasikan dari nilai korelasi ( $r$ ) sebesar 0,676 . Detritus adalah bahan organik, yang di Danau Singkarak terutama berasal dari buangan

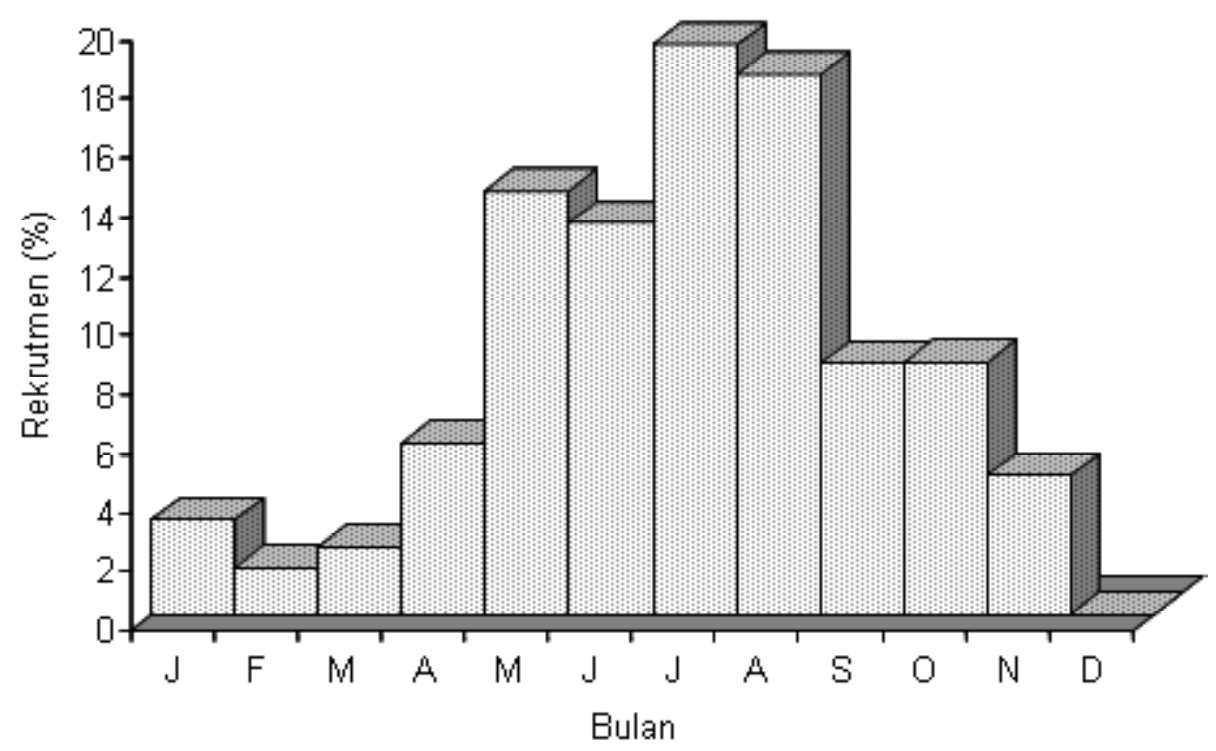

Gambar 5. Pola rekruitmen ikan bilih di Danau Singkarak. 


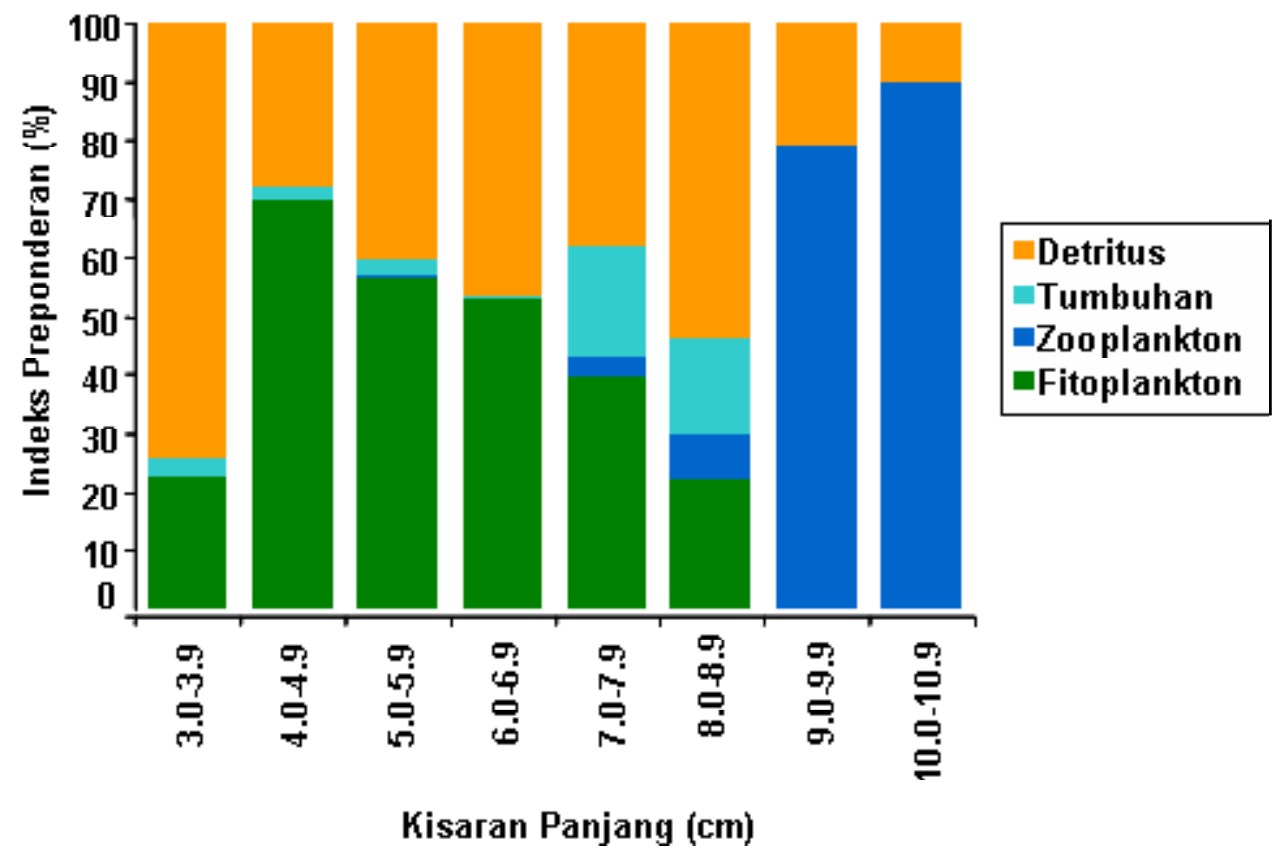

Gambar 6. Kisaran panjang dan komposisi makanan ikan bilih di Danau Singkarak.

domestik atau pemukiman yang banyak terdapat di daerah pesisir danau. Di sisi timur danau yang berbatasan dengan jalan raya Lintas Sumatera banyak sekali dijumpai rumah makan yang secara tidak langsung merupakan penyumbang bahan organik allochthonous (bahan organik berasal dari luar perairan) bagi biota perairan, khususnya ikan bilih. Bertolak dari makanan yang dikonsumsinya maka ikan bilih dapat dikategorikan sebagai jenis ikan yang bersifat detritivora atau planktivora.

\section{KESIMPULAN}

1. Pertumbuhan ikan bilih di Danau Singkarak bersifat allometrik positif dan dapat tumbuh sampai mencapai panjang $11,6 \mathrm{~cm}$ dengan laju pertumbuhan 0,50 per tahun.

2. Laju eksploitasi stok ikan bilih sudah mencapai 0,52 , artinya bahwa upaya penangkapan ikan ini sudah mulai dikendalikan atau dikelola secara ketat.

3. Ikan bilih bersifat detritivora, makanan utamanya adalah detritus $(38,9 \%)$ dan makanan pelengkapnya adalah fitoplankton $(33,1 \%)$ dan zooplankton $(22,6 \%)$ serta makanan tambahan berupa tumbuhan air (5,4\%).

\section{PERSANTUNAN}

Kegiatan dari hasil riset analisis kebijakan sumber daya perikanan di Danau Singkarak dan Waduk
Wadas Lintang, T. A. 2003 dan 2004, di Pusat Riset Perikanan Tangkap-Ancol, Jakarta.

\section{DAFTAR PUSTAKA}

Anhariah. 1988. Studi aspek reproduksi ikan bilih (Mystacoleucus padangensis Blkr) di Danau Singkarak. Skripsi. Fakultas Perikanan Institut Pertanian Bogor. Bogor.

Dulèiæ, J., A. Pallaoro, P. Cetiniæ, M. Kraljeviæ, A. Soldo, \& I. Jardas. 2003. Age, growth, and mortality of picarel, Spicara smaris L. (Pices: Centracanthidae), from the eastern Adriatic (Croatian coast). J. Appl. Ichthyol. 19 (2003): 1014.

Effendie, M. I. 1979. Metoda Biologi Perikanan. Cetakan pertama. Yayasan Dewi Sri. Bogor.

Gayanilo Jr F.C., P. Sparre, \& D. Pauly. 1995. The FAO-ICLARM stock assessment tools (FISAT) User's guide. FAO computerized information series: fisheries. ICLARM Contribution. 1.048: 126 pp.

Gulland, J. A. 1983. Fish stock assessment: A manual of basic methods. Chichester. U. K. Wiley Interscience. FAO/Wiley Series on Food and Agriculture. 1: $223 \mathrm{pp}$.

Kottelat, M., A. J. Whitten, S. N. Kartikasari, \& S. Wiroatmodjo. 1993. Freshwater fishes of Western 
Indonesia and Sulawesi (Ikan air tawar Indonesia Bagian Barat dan Sulawesi). Periplus Editions Ltd. Indonesia.

Pauly, D. 1980. A selection of simple methods for the assessment of tropical fish stocks. FAO Fish. Circ. 729: $54 \mathrm{pp}$.

Pauly, D. 1982. Studying single species dynamics in a tropical multispecies context. In D. Pauly \& G. I. Murphy (eds.). Theory and management of tropical fisheries. ICLARM Conf. Proc. 9. 33-70.

Pauly, D. \& M. L. Suriano. 1986. Some practical extensions to Beverton and Holts's relative yieldper-recruit model. In J. L. MAclean, L. B. dizon, \& L. V. Hosillos (eds.) The First Asian Fisheries Forum. Asian Flsh. Soc., Manila. Philippines. 491495.

Prabha, Y. S. \& C. Manjulatha. 2008. Food and feeding habits of Upeneus vittatus (Forsskall, 1775) from Visakhapatnam Coast (Andhra Pradesh) of India. Int. J. Zool. Res. 4 (1): 59-63.

Purnomo, K. 1994. Beberapa aspek biolimnologi dan sumber daya perikanan di Danau Singkarak. Bulletin Penelitian Perikanan Darat. 12 (2): 166170.

Purnomo, K., E. S. Kartamihardja, \& S. Koeshendrajana. 2003. Pengelolaan populasi ikan bilih (Mystacoleucus padangensis) di Danau Singkarak, Sumatera Barat. Warta Penelitian Perikanan Indonesia. 9. 5: 2-10.
Purnomo, K., E. S. Kartamihardja \& S. Koeshendrajana. 2006. Upaya pemacuan stok ikan bilih (Mystacoleucus padangensis) di Danau Singkarak. Prosiding Seminar Nasional Ikan IV. Jatiluhur 29-30 Agustus 2006. Masyarakat Iktiologi Indonesia bekerjasama dengan Loka Riset Pemacuan Stok Ikan-Departemen Kelautan dan Perikanan. Departemen Manajemen Sumber Daya Perairan-Institut Pertanian Bogor. Pusat Penelitian Biologi-Lembaga Ilmu Pengetahuan Indonesia.

Purnomo, K. 2008. Pengelolaan sumber daya ikan di Danau Singkarak. Prosiding Semnaskan Indonesia. 4-5 Desember 2008. Sekolah Tinggi Perikanan. Jakarta. 437-444.

Ricker, W. E. 1975. Computation and interpretation of biological statistics of fish populations. Bull. Fish. Res. Board. Can. 119: 191-382.

Syandri, H. 1996. Aspek reproduksi ikan bilih (Mystacoleucus padangensis Blkr) dan kemungkinan pembenihannya di Danau Singkarak. Tesis. Doktor Program Pascasarjana. Institut Pertanian Bogor. Bogor.

Syandri, H., Murniwira, \& Azrita. 2001. Kebijakan pengelolaan plasma nutfah ikan bilih (Mystacoleucus padangensis Blkr) endemik untuk kelestarian alam dan pembangunan berkelanjutan di Danau Singkarak. Laporan Akhir Kerjasama antara Badan Perencanaan Pembangunan Daerah Kabupaten Solok dan Lembaga Penelitian dan Pengabdian kepada Masyarakat Universitas Bung Hatta. Padang-Sumatera Barat. 